\title{
Beni Suef- Pearl of Upper Egypt- and its Role in Sustainable Tourism Development
}

\author{
Waleed Radwan Mahfouz Ibrahim Radwan \\ Department of Tourism Studies, Faculty of Tourism and Hotel Management, Helwan \\ University, Cairo, Egypt
}

\section{ARTICLE INFO ABSTRACT}

Keywords:

Beni Suef

governorate,

Meidum Pyramid;

Tourism

Development;

Monuments.

(JAAUTH)

Vol. 21, No. 4

(December 2021),

PP.134-157.
Beni Suef province is one of the most promising provinces in Upper Egypt, characterized by a strategic location, integrated vision and executive expertise that contribute to put the province on the investment and tourism map. Beni Suef is one of the most important provinces located south of Egypt's capital, Cairo, with many important touristic attraction places in the province. It is characterized by the presence of many Pharaonic, Islamic, and Coptic relics, as well as a museum containing many monuments from different periods such as Roman, Pharaonic, Greek, Coptic and Islamic, in addition to Wadi Sannor Cave Protectorate Area, where this cave dates back 65 million years. The main data collection method involved in-depth, semi-structured interviews with government officials at General Authority of Tourism Development, second phase involved a questionnaire administrated to students at the faculty of tourism and hotelsBeni Suef University, where third phase involved a questionnaire conducted with a sample of citizens in Beni Suef governorate. The paper recommends that the Ministry of Tourism and Antiquities should merge Beni Suef governorate in the path of the Holy Family as an attractive tourism product, where the governorate is considered a link between the points of the path of the Holy Family located in Cairo (at the Virgin Church in Maadi) and the same track points located in Minya (the first of which is Jabal Al-Tair), also, Beni Suef governorate in collaboration with the General Authority of Tourism Development should spread tourism and archaeological awareness among the masses of the citizens of Beni Suef adjacent to tourist and archaeological sites in order to cooperate easily with tourists.

\section{Introduction}

Most of the local community in Beni Suef province, consider it to be one of the poor tourist provinces, because of the lack of tourist places in it, and the majority of its citizens go to other provinces to enjoy Religious and Pharaonic tourist places, on the grounds that they contain only the Pyramid of Meidum, the Museum, the plane of 
October War 1973 between Egypt and Israel, and the zoo (Fathy, 2017). However, Beni Suef is relatively rich in terms of its tourism resources, whether archaeological, natural, environmental and climatic, as the most important tourist components in the province are the presence of Wadi Sannor Cave Protectorate Area, Beni Suef Governorate Museum and many elements of archaeological and historical tourism throughout the Pharaonic, Roman, Coptic and Islamic times, and natural and recreational components in which the province has a distinctive set of features (ElKholy, 2021 and Ragab, 2020).

Beni Suef Governorate is considered a distinctive part of Egypt, with regard to its important components and resources, the province can reach a unique position agriculturally, industrially, commercially and touristically, where it is famous for combining the agricultural and desert nature, and is a historical museum open to all periods "Pharaonic, Coptic and Islamic". The province of Beni Suef is full of rare natural phenomena where its population of more than three million citizen feel proud of their ancient historical city, and its religious and tourist sites spread throughout the province, where The Pyramid of Meidum is considered the oldest historical witness to the greatness of this place, the second oldest pyramid in the world built by King Huni, the last king of the Third Dynasty, and completed by King Sneferu, founder of the Fourth Dynasty (General Information Authority, 2021).

\section{Research Question}

The current research is designed to answer the following question: "To what extent can the touristic sites in Beni Suef contribute in the tourism development of the governorate?

\subsection{Aim and Specific Objectives}

The study aims to explore the main touristic attractions in the governorate of Beni Suef, and how to develop it in a good way, as the province is very rich and unique in its touristic sites, where the most important tourist attractions is represented in Pharaonic, Coptic and Islamic Antiquities Sites, Wadi Sannor Cave Protectorate Area, Beni Suef Governorate Museum, in addition to other touristic sites inside the province.

In order to fulfill this aim, five specific objectives were undertaken:

2.1.1 Illustrate The History of Beni Suef

2.1.2 Explore Beni Suef Governorate

2.1.3 Overview the Concept of Tourism Development and Sustainability

2.1.4 Demonstrate the Main Touristic Sites in Beni Suef

2.1.5 Explore the Role of the Government in Developing Tourism in Beni Suef

\section{Review}

\subsection{The History of Beni Suef}

The name "Beni Suef" was recently used for the province, as during the Pharaonic period, it was called "Boveca", one of the oldest sacred Egyptian cities in the Nile Valley, which played a leading role in ancient Egyptian civilization and was the headquarter for King Neswet, one of the kings of ancient Egypt, before the unification of the northern and southern countries of Egypt by King Mina (Narmer) and was also 
the capital of the country during the 9th and 10th Pharaonic dynasties (2240-2100 B.C.) (Saleh, 2021).

It continued to play this important role during the Greek and Roman periods, where it was classified as one of the best cities in Egypt on the banks of the Nile and in the Coptic, language was known as (Pani Soof), and during the Arab conquest of Egypt, the name was deviated from (Boveca) to become (Minvesia), which facilitates its pronunciation in the Arabic language (Beni Suef Governorate Electronic Gate, 2021).

In $1527 \mathrm{AD}$, the name was transformed into Beni Youssef, a proportion of a Bedouin Arab tribe that lived in that area, and during the French campaign against Egypt led by Napoleon, Beni Suef became the capital of that region due to its strategic importance, and it became a directorate in $1858 \mathrm{AD}$ and its capital was the city of Beni Suef (Saleh, 2021 and Hafiz, 2021). After the revolution of July 23, 1952, the term directorate changed to a province, where the modern and contemporary province was established (Beni Suef Governorate Electronic Gate, 2021).

\subsection{Beni Suef Governorate}

Beni Suef is one of the governorates of Egypt located 120 kilometres south of Cairo, and shares its borders with four provinces: Giza, the Red Sea, Fayum and Minya (Beni Suef Governorate Electronic Gate, 2021). The area of the province represents only about $1 \%$ of the total area of the Arab Republic of Egypt, where its area is about 10,954 square kilometres. It is famous for combining the agricultural and desert aspects, and it is particularly important in terms of the production of fruits, vegetables and aromatic plants, where agricultural land accounts for $12 \%$ of the total area of the province, while the area of desert land is about $88 \%$, this combination of agricultural and desert nature has led to this province enjoying a unique and wonderful diversity in the plant and wild environment (Saleh, 2021). The total population of Beni Suef governorate in 2020 is about three million, and about $76.5 \%$ of the total population of the province resides in rural areas (Beni Suef Governorate Electronic Gate, 2021), which means that less than a quarter of the province's population resides in its urban centres (General Authority for Tourism Development, 2016).

Beni Suef province is connected to tourist transport centers in the Republic and the capital through a network of good main roads such as Western Assiut road, the Eastern Road of the Army and the Eastern road Beni Suef- Koraymat which is one of the most efficient roads in the network. As for the road network between the province's cities is a medium-connected network that can be developed to serve the province's tourism activity and facilitate transportation between its tourist areas. The province suffers from the poor condition of internal roads within the centres and villages, where the proportion of dirt roads rises to $43.14 \%$ of its total length. The main railway line Cairo-Aswan passes through the province linking the province to the provinces of the valley. Also, Beni Suef has competitive features on the Nile, a long-distance Corniche and a waterway that is the largest and shows the Nile Islands as a masterpiece (Amer, 2016 and Serag El-Deen, 2012).

The governorate of Beni Suef is severely deficient in tourist accommodation. There are only a few mid-level accommodations such as City Center Hotel Beni Suef, Jewel 
Inn Beni Suef, Al-Assiouty Sport Resort, Bostan Alward Hostel, Ibiza Garden, La Viena Health Resort, Marina Coast, and Country House in Meidum (El-Sheikh, 2021).

The logo of Beni Suef province reveals many of the meanings and secrets of the province. The province's motto refers to its ancient past, embodied in the image of the "Pyramid of Meidum", and celebrates its thriving present, where wheat represent the agricultural activity, and the chimney symbolizes industrial activity. At the same time, this slogan predicts the future of the province, where this slogan represents the flow of the Nile River, topped by the Beni Suef Bridge, which extends to connect the two sides of the province on the two banks of the Nile (El-Garhy, 2021 and Dar El-Helal, 2020).

Beni Suef's National day is $15^{\text {th }}$ of March every year, where the local community of Beni Suef celebrate each year, in memory of the solidarity of its people with the revolution of 1919 led by the national leader Saad Zaghloul (Saleh, 2021 and Mohsen, 2020).

\subsection{Main Touristic Sites in Beni Suef \\ 3.3.1 Pharaonic Antiquities Sites}

Beni Suef governorate is one of the most important archaeological and tourist provinces and a historical museum of all periods containing many of Egypt's treasures, where Beni Suef region contained two of Egypt's upper regions, the city of Al-Haiba and Ahnasia. Pharaonic monuments vary in centers and villages such as: Meidum, Abu Sir, Ahnasia-The Cemetery of Sedmant Al-Jabal, Dashasha, and AlHaiba.

\subsubsection{The Area of Ahnasia}

The area of Ahnasia was the capital of the ancient Egyptian state during the reign of the ninth and tenth dynasties for nearly two centuries" 2242, 2452 B.C.," known as Ahnnis, from which the current name is Ahnasia, where it belongs to the family of Pharaoh Shaqmmos, and the area of the archaeological area is about 390 acres. It is one of the most important ancient Egyptian cities, and during certain periods was one of the capitals of the country (Kasem, Bakry, and Abd-El-Mawgod, 2014). Ahnasia continued its importance throughout the Pharaonic era as evidenced by the Roman and Byzantine relics found in Ahnasia, where a collection of tombs from the 22 dynasties with different inscriptions and decorations was found, and the remains of the pillars of the Roman temple still exist in the area (Fathy, 2017).

The main cemetery of the area of Ahnasia, exist in the village of Sedmant Al-Jabal, which has many tombs dating back to the period of King "Den" from the first dynasty and the cemetery "Mry, Wra'a, and Hatchf" that belongs to the fifth dynasty. There is also the tomb of Prince Ra, Hotop and his wife", which extends approximately three $\mathrm{km}$ in length and 500 meters width. Also, there are traces of Roman times between 30 B.C., and 390 A.D. that were found in Ahnasia Area (Kasem, Bakry, and Abd -ElMawgod, 2014).

During the rule of the Ptolemaic period, Ahnasia was a place of worship and a cultural center in Egypt. The Greek rulers tried to find harmony between their gods 
and the ancient Egyptian gods, and attributed the ancient Egyptian god Harchev to the god of Hercules, hence Ahnasia is known among archaeologists "Heracliopolis" and the word "Magna" means in Arabic "great" (Shaheen,2021).

\subsubsection{Meidum Antiquities Area}

Beni Suef province has many Pharaonic touristic places, where Meidum Archaeological Area is considered to be one of the most distinctive sites, where it is located west of the Center of El-Wasta, situated north of the province (Fathy, 2017). It was called "Wmer-Atum" in ancient Egyptian language that means the beloved of God Atum, which is the most important archaeological site, where one of the most famous and important thing in this site is the Pyramid of Meidum (El-Weshahy and Abd El-Wahab, 2016).

The region is distinctive due to the beauty of Meidum pyramid that was built in the Old Kingdom by King Huni, the last king of the third dynasty and completed by King Sneferu, the first king of the fourth dynasty and the father of King Khufu, who built the great pyramid of Giza (El-Weshahy and Abd El-Wahab, 2016).

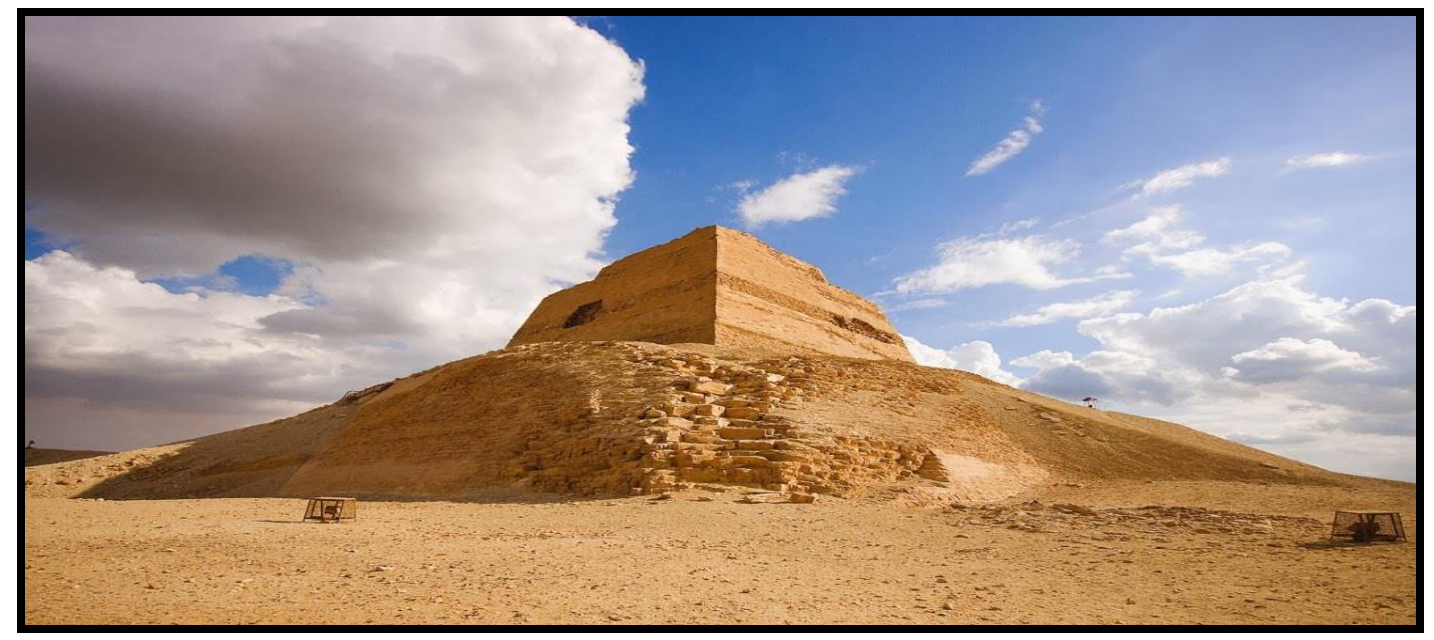

\section{Source, Meidum Pyramid, 2021}

The pyramid consisted of eight Steps of which only three currently existed of 45 meters high (Fathy, 2017 and N-Egypt, 2019), and was the second oldest pyramid after the pyramid of King Djoser in Saqqara and the fifth largest pyramid in Egypt when it was created. Next to the pyramid, there are many tombs dating back to the ancient time (Nour El-Deen, 2001).

\subsubsection{Cemetery of Abu Sir}

It is located about $15 \mathrm{~km}$ north-west of Ashment town, about $15 \mathrm{~km}$ north of Meidum and following the Center of Wasta and was the seat of the worship of the God Osiris (Fathy, 2017). The area includes a group of Cemeteries from different periods, which reach the depths of about 14 meters, where there are tombs from the pre-dynasties, the first and second dynasty and from the Old Kingdom were found, and some tombs from the New Kingdom, all carved in rock, and some monuments from the 26th dynasty and rocky tombs from the Greek-Roman periods were found. This area is a 
wonderful archaeological area that attracts many tourists to visit (Tourism Promotion Authority in Beni Suef, 2019).

\subsubsection{Area of Dashasha}

In Beni Suef province, there is the area of Dashasha, which is located 15 kilometers southwest of Ahnasia City and its cemetery belong to the Old Kingdom, where there are many Pharaonic archaeological tombs that have existed for thousands of years (Fathy, 2017). The area includes a cemetery from the fifth dynasty, the most important of which are two tombs, one of them named "Shado" and the other tomb "Enty", which are located inside the mountain and have inscriptions representing the daily life and the battles that their owners fought during their lives (Kasem, Bakry, and Abd-El-Mawgod, 2014).

\subsubsection{Area of Al-Haiba}

The Area of Al-Haiba is located about $5 \mathrm{~km}$ from the city of Al-Fashn, eastern side of the Nile, where the city was known in ancient Greek texts as "Hibons" and became Al-Haiba in the Arabic language. It has the remains of a temple that was built by King Shoshenq I, one of the kings in the 22nd dynasty of the goddess Amon. In the area of Al-Haiba, a papyrus was found that registered the story of the priest "Wenamun" who went to Byblos in Lebanon, to bring the cedar wood necessary to build the sacred boat of The God Amon (N-Egypt, 2019\& Kasem, Bakry, and Abd-El-Mawgod, 2014).

\subsubsection{Sedmant Al-Jabal Archaeological Area}

This cemetery is located to the west of the City of Ahnasia on the western land of Bahr Youssef between Sedmant Al-Jabal and Mayana, where there is a series of tombs of the Old Kingdom (Tourism Promotion Authority in Beni Suef, 2019).

\subsubsection{Abweit Antiquities Area}

It is a Cemetery that returns back to the Greek-Roman period with an area of about 40 acres south of Kom Abu Rady about 2 km (Kasem, Bakry, and Abd -El-Mawgod, 2014).

\subsubsection{Eastern Nile Areas of Beni Suef Center}

It includes many archaeological areas, such as: Sherif Pasha Area, Eastern Beni Soliman Antiquities Area, and Abu Hashimah Antiquities Area in The Semsta district (Kasem, Bakry, and Abd -El-Mawgod, 2014).

\subsubsection{Coptic Antiquities Sites}

There are many Coptic monuments that exist throughout Beni Suef province from churches and monasteries such as the Monastery of the Virgin Mary in Bayyad AlArab east of Beni Suef dates back to the 14th century; Saint George Monastery in Sedmant Al-Jabal dates back to 683 AD, where the monastery is located west of Sedmant Al-Jabal, in the center of Ahnasia city (Tourism Promotion Authority in Beni Suef, 2019); the Church of the martyr Saint George which is located in Bba and dates back to the year 1830; the Monastery of Anba Antonios in the Maimon area known as Deir Al-Maimon; Al-Anba Monastery in Naser district (Kasem, Bakry, and Abd-El-Mawgod, 2014). 
Also, there is the Monastery of Virgin Mary in Al-Hammam Area which is known as Al- Hammam Monastery, where it is located $6 \mathrm{~km}$ northwest of Al-Lahoon, west of the village of Hammam on the Central Dirt Road, and now the monastery is located directly on the Western Desert Road of Beni Suef-Fayoum. It is one of the oldest monasteries in Beni Suef province, where it dates back to the fourth century AD, where the Monastery is known as Virgin Mary and was attached to the word "bath" relative to the village where the monastery is located, in addition, the village is named after "the bath" because of the large bathrooms in the area, for princesses, which date back to Greco-Roman times (Saleh, 2021).

\subsubsection{Islamic Antiquities Sites}

The governorate of Beni Suef have many Islamic archaeological mosques with a long and distinguished history including the minaret of the Grand Mosque "Delas", which dates back to the Fatimid period, and reaches a height of 14 meters, which is an eightform building, consisting of four floors decorated with geometric decorations that resemble the Sunlight (Fathy, 2017); Mosque of Omar Ibn-Abdul Aziz, which is one of the modern mosques that characterizes Beni Suef Governorate; Al-Ghamrawi Mosque that was established in 1316 Ah by Mustafa Kamel Pasha Al-Ghamrawi and assisted him in the design an Italian engineer to combine Italian design with Islamic art; Marawan Ibn Mohammed Shehab Al-Din Umayyad cemetery, which is located in the village of Abu Sir, the last state of the Umayyad state (Kasem, Bakry, and Abd El-Mawgod, 2014).

In addition, there is Al-Diri Mosque, which is one of the most famous historical mosques in Beni Suef, inaugurated by King Farouk, after it was built by Hammam bin Darwish Al-Diri in $1327 \mathrm{Ah}$, and is considered one of the first mosques that joined the Islamic Antiquities Authority, and the Mosque of Houria in the city of Beni Suef, where it is considered the most famous among other mosques in the province from Wasta to Al-Fashn in the south, as it is characterized by the presence of a mausoleum to one of the granddaughters of Imam Hussein bin Ali (Fathy, 2017).

\subsubsection{Cultural Touristic Sites}

\subsubsection{Beni Suef Governorate Museum}

The Beni Suef Museum is located in Beni Suef, the provincial capital, which has witnessed some important periods in Egypt's history and still retains many important archaeological sites such as Ahnasia, Meidum, Dashasha, and Abu Sir (Fathy, 2017 and El-Mahdy, 2021). The museum opened in 1997 with two floors, where the first floor houses Egyptian antiquities found in archaeological sites in the province from Prehistoric times and throughout the Pharaonic period, as well as the Greco-Roman periods. The second floor includes Coptic and Islamic antiquities and some of the belongings of Mohammed Aly's Family (Fathy, 2017 and El-Mahdy, 2021).

The museum is designed in the form of the Pyramid of Meidum, where one of the most important collections of the Pharaonic era inside the museum is a collection of statues of kings, Gods, individuals, funeral paintings, human coffins and pots, i.e. canopy pots and amulets. From the Greek and Roman periods, there is a collection of statues of individuals, gods and funeral paintings. Some of the icons, metal and 
wooden tools and models of Coptic fabric are among the Coptic monuments. Islamic monuments include wooden doors and manuscripts, and belongings of the Mohammed Aly's Family display various types of ceramics, weapons and clothing (El-Mahdy, 2021).

\subsubsection{Wadi Sannor Cave Protectorate Area}

The area is considered a natural reserve under Prime Minister's decision no. 1204 of 1992. The Sannor Valley Cave is $70 \mathrm{~km}$ southeast of Beni Suef City, about 700 meters length, 15 meters wide and 15 meters depth (Ragab, 2020). It is considered one of the most important tourist attractions in Beni Suef province, aged 65 million years and is one of the most important nature reserves in the Republic, and the third oldest nature reserve in the world and has a very large historical importance (ElSheikh, 2020).

Wadi Sannor Cave is a distinctive site, where it is a unique phenomenon in Egypt and even in the world, and shows in the cave the protrusions of Clece, which may be transparent like glass, white ones like snow, what looks like long glass pipes, and what resembles coral reefs (Fathy, 2017). The reserve is located near the Village of Sannor, which is situated on the east bank of the Nile River and $18 \mathrm{~km}$ from the Nile Bridge, and the protected road begins in front of the village on a paved desert road about 60 kilometers long in the southeast direction known as the Marble Trail (Fathy, 2017). The Sannor Cave was open to visitors but there were some cracks in the entrance of the cave, and it was closed and is now restored (Ministry of Tourism and Antiquities, 2021).

\subsection{Tourism Development and Sustainability}

Tourism has been considered as a particular helpful choice for developing countries, where significant resources have been invested in tourism through communities and governments, also residents commit time, money and effort in tourism hoping it will bring a variety of economic and social benefits to their communities (UNDP, 2017). Also, Tourism has become one of the world's most important sources of employment, as it encourages vast investment in infrastructure, most of which also facilitate in improving the living conditions of local people (Pender and Sharpley, 2005), also it provides governments with huge tax revenues, where most new tourism jobs and business are created in developing countries, helping to equalize economic opportunities (Saufi, A., O’Brien, D., and Wilkins, H., 2014).

Tourism development in any destination needs proper participation of all stakeholders, particularly local residents' involvement in decision-making of tourism development process (Theobald, 2005). This is because the impacts of tourism development are felt mostly by local residents, as well as local residents are considered to be an important factor supporting tourism development for any destination (Amerta, 2018). However, decision-makers and planners often in the developing countries, e.g. Egypt, tend to involve government officials and developers without a full consideration of local residents participation in tourism development (Weaver and Lawton, 2006). This matter affects securing local residents' benefit and support toward tourism development (Murphy and Murphy, 2004). 
The notion of sustainable tourism has its roots within the idea of sustainable development commonly and may be referred to as the growth that achieves the aims of the time being without compromise the aims of potential generations to fulfill their requirements (Cernat, and Gourdon, 2007). As the tourism industry turned to be progressively more vital to communities all over the world, the requirement to develop the sustainability of tourism has become a priority (Amerta, 2018).

Sustainable tourism can be defined by the UN Environmental Program and UN World Tourism Organizations as:

"Tourism that takes full account of its current and future economic, social and environmental impacts, addressing the needs of visitors, the industry, the environment and host communities." (Global Sustainable Tourism Council, 2021, p.1).

The concept of sustainability has gained much support, as a means of re-establishing the balance between economic, social, and environmental goals. Emphasis is placed on long term objectives (Ashley, 2007). Sustainable tourism is about managing tourism development in an acceptable way to ensure changes to the environment are kind. It is not about denying any development at all (Global Sustainable Tourism Council, 2021).

\subsection{The Role of the Government in Developing Tourism in Beni Suef}

The development vision of the tourism sector indicates that Egypt should be a sustainable and attractive tourism destination at the regional and international level, and a fundamental supporter of the national economy and the sustainable development. The strategy for achieving this vision is done, in accordance with the economic and social development plan in six points (Fakhry, 2021):

1) Improving the quality of the tourism product while strictly adhering to environmental standards and green tourism to ensure sustainability

2) Diversifying the tourism product by targeting new tourist patterns, such as ecotourism, sports tourism, and safari tourism

3) Diversifying foreign markets to attract visitors from emerging economies that are moving towards greater openness, as well as countries that are recovering from Corona virus as the starting point for promotional activities for Egyptian tourism

4) Intensifying training programmes in the tourism sector to develop the capabilities and skills of workers.

5) Intensive promotion of archaeological collections to support cultural tourism through conferences and promotional missions, participation in international exhibitions and celebrations of the opening of the Great Egyptian Museum, and the announcement and promotion of modern archaeological discoveries globally in accordance with innovative technological methods.

6) Spreading public awareness and spreading tourism culture in schools, universities, and various media to highlight the economic importance of tourism and its key 
role in developing sources of income in foreign exchange, increasing employment levels, and achieving cultural convergence and social peace among people.

According to the development vision of the tourism sector, Beni Suef governorate started in implementing this vision, where Beni Suef province remained neglected for a long time ago until a tourism development strategy was prepared by the government over the next five years as part of Egypt's 2030 Vision for Sustainable Development, where the Governor of Beni Suef, held a meeting with a delegation from the Ministry of Development, headed by the Director of the Local Administration Development Unit, and Director of the Local Development Program in Upper Egypt, the Director of the Project for Workforce Development and Skills, with the aim of gaining the province's rightful place in the Egyptian tourism map (El-Garhy, 2021).

The tourism development strategy for the province included in a comprehensive survey of the components of the province in this field, studies of economic feasibility, obstacles and challenges existing, and proposals to invest these components, where the Economic Development Unit that is carrying out this important development work in cooperation with the economic advisory council of the province (Saleh, 2021 and Soliman, 2020).

The tourism development strategy aimed at including the province of Beni Suef in a privileged position on the Egyptian tourist map. In order to do so, many projects have been developed such as: investing in the availability of 27 islands along the province, developing the Archaeological Museum of Beni Suef, providing tourism services that help attract tourists, providing training and rehabilitation programs to work in the required tourism field, in addition to providing various promotional plans. The purpose of this trend is to maximize the value-added chains of each tourist site, as this will increase economic returns and create more jobs for youth (Aly, 2021).

In order to transform Beni Suef governorate into a unique touristic attraction, many projects started to be implemented such as: the project of developing the Nile Corniche area in Beni Suef, the project of developing the area of Oasis and the Meidum Pyramid, setting a practical and economical viable picture to develop the Sannor Cave Protectorate area and transform the area to distinguished tourist attraction, promoting the area of Al-Haiba, which was allocated to be a tourist resort, which is $37 \mathrm{~km}$ close to the Sannor Cave Reserve, in addition to develop the Palace of Culture east of the Nile (El-Garhy, 2021).

The General Authority for Tourism Development provided a scientific vision and detailed designs for the Golden Triangle Area, and the possibility of executing many fields there, whether tourism, commercial, real estate, entertainment, culturally, and other activities that contribute to the investment of the distinguished area, as it is considered a meeting point for three provinces, namely Giza, Beni Suef and Fayoum (Rezk, 2020).

Currently, Beni Suef governorate in collaboration with other sectors in the province setup a development plan in order to occupy a special location on the Egyptian tourist map "locally and internationally" to support the province developmentally, by achieving a number of objectives, the most important of which are: increasing the 
number of tourists in the province, increasing the number of nights of residence, increasing the resources of the province from the tourism sector, developing new projects that contribute to the development of setting the province in the tourism map, and providing new jobs in this sector (El-Kholy, 2021 and El-Sheikh, 2020).

\section{Methodological Approach}

This study analyses the role of Beni Suef governorate in the sustainable tourism development. Three main phases of fieldwork and data collection were conducted: The first phase involved in-depth, one-to-one, semi-structured interviews with government officials and experts at General Authority of Tourism Development, the second phase involved a questionnaire administrated to students at the faculty of tourism and hotel management- Beni Suef University, where the third phase involved a questionnaire conducted with a sample of citizens in Beni Suef governorate.

The first phase involved in-depth, one-to-one, semi-structured interviews with government officials and experts (four at General Authority of Tourism Development) to illustrate how to develop tourism in Beni Suef governorate in an effective way, and the main projects that had been executed to develop the province or is currently being implemented such as the Development of the Area of Meidum Oasis, the investment in Golden Triangle Touristic Area and the development of Nile Tourism and Corniche in Beni Suef Governorate

The second phase involved a questionnaire that was directed to a sample of students at the faculty of Tourism and Hotels- Beni Suef University- Fourth year- in the academic year 2020-2021- English and Arabic Section, where the total number of students in the two sections represent 46 students (24 students in English section and 22 students in Arabic section). The questionnaire was distributed to thirty-five students that used to attend regularly at the faculty, where 30 forms were returned representing $86 \%$ of the sample. The questionnaire was directed to the students within two months (November 2020- December 2020).

The third phase aimed to seek feedback from a sample of local community in Beni Suef governorate. The questionnaire comprised two sections. The first section was designed to gather demographic information about the citizens such as their gender, age, and level of education; the second section gathered feedback to illustrate the Citizen's knowledge about the main touristic sites in Beni Suef, and whether they visited these touristic sites or not. The questionnaire was distributed to 120 citizens from the local community, where 105 forms were returned, and representing $87.5 \%$ of the sample. The questionnaire was directed to the local community within two months (June 2021- July 2021).

\section{Research Findings}

\subsection{Experts at General Authority of Tourism Development "Personal Interviews"}

Based upon the in-depth, one-to-one, semi-structured interviews with four government officials and experts at the General Authority of Tourism Development, the following issues were highlighted: 


\subsubsection{The Development of the Area of Meidum}

In order to develop the area of Meidum, many projects had been implemented such as developing the great hall in the area to be converted into an archaeological museum; giving the cultural form to the area and qualify it to receive visitors by supporting it with basic services; the possibility of establishing bazaars in the area of Meidum; the open area in the Oasis is also equipped with a cafeteria and restaurant; the lighting of the area of Meidum Pyramid and the establishment of an integrated touristic city near the Area of Meidum Oasis in Wasta Center.

In addition, the province adopted a new strategy in coordination with the Ministry of Tourism and Antiquities, to develop future plans for the development of Meidum Pyramid especially after the Ministry of Tourism included "Meidum" Pyramid as part of the program of visiting the pyramids in Giza.

"The development of Meidum Oasis has started to be implemented in order to transform the area into a civilized outlet and tourist attraction, where work is carried out to give the cultural form to the area and qualify it to receive visitors by supporting it with basic services and needs in preparation for the comprehensive development as part of the tourism development strategy"

[Expert 2]

"In order to develop the area of Meidum Oasis, the great hall in the area was developed and equipped for the possibility of converting it to an archaeological museum that demonstrates the archaeological importance of the area, which contains the Pyramid of Meidum, which was completed by Sneferu, the founder of the fourth dynasty, which is the first completed pyramid and is the oldest even from the Pyramids of Giza."

[Expert 1]

"The possibility of establishing bazaars in the area of Meidum, through which the most important Pharaonic and archaeological collections are displayed"

[Expert 3]

"The open area in the Oasis is also equipped with a cafeteria and restaurant in which it serves the traditional and popular meals that characterize the province and is a tradition and cultural heritage, equipping an area for horses, camels and war wheels, beautifying the oasis through trimming trees, installing ornamental plants and roses, raising the efficiency of basic services, such as the efficiency of the toilets has been increased in the Oasis".

[Expert 1]

"One of the most important projects is the establishment of an integrated touristic city on an area of 2,124 acres near the Area of Meidum Oasis in Wasta Center, which will contribute to achieving a tourist shift in the province and put it in a privileged position with the map of Egypt tourism locally and internationally".

[Expert 4] 
"Among the projects for tourism development in the Area of Meidum Oasis is the lighting of the area of Meidum Pyramid as part of the tourism development strategy, where the electricity infrastructure and the installation of ground scouts in the area was established."

$$
\text { [Expert2] }
$$

"The province adopted a new strategy in coordination with the Ministry of Tourism and Antiquities, to develop future plans for the development of tourism in the oasis of Pyramid of Meidum, in order to put Beni Suef on the local and international tourist map, especially after the Ministry of Tourism and Antiquities included the pyramid "Meidum" as part of the program of visiting the pyramids in Giza, and promotional activities for pyramids on the global agenda."

$$
\text { [Expert 1] }
$$

\subsubsection{Investment in Golden Triangle Touristic Area}

The General Authority for Tourism Development setup a scientific vision for the Golden Triangle Area, and started to execute many fields their, such as tourism, commercial, entertainment, culturally, and other activities that contribute to the investment of the distinguished area.

"There is an area of 2,124 acres allocated for tourism investment, called the Golden Triangle, where it represents the meeting point of three provinces (Giza, Fayoum and Beni Suef), which are located opposite the Meidum Oasis, and the province of Beni Suef has placed it among its objectives with the tourism development strategy for the next five years, till 2025."

[Expert 1]

\subsubsection{Development of Nile Tourism and Corniche in Beni Suef Governorate}

The General Authority of Tourism Development has developed a development plan for Nile tourism aimed at developing all tourist anchors located on the tourist route of Nile cruises to serve cruise ships and stimulate tourism for archaeological areas and tourist destinations along the Nile River

"The tourism development strategy for Nile tourism depends on the implementation of the development plan on several consecutive stages, including the first phase of the development of overnight anchors in Beni Suef, Minya, Assiut-Sohag, while the second phase includes the improvement of the visiting anchors in Bani Hassan- Tel Al-Ammarna-Al-Balina- Naga Hammadi) with the rest of the marinas to be completed respectively."

[Expert 4]

"The development of overnight anchors has been implemented by $100 \%$ at a total cost of EGP 5.5 million, and the development of the visit anchors was implemented by $50 \%$ at a total cost of 2.2 million pounds where the implementation of the marina of Tel Al-Ammarna in Minya governorate and the Marina of Al-Balina in Sohag governorate was completed."

[Expert 1] 
"The practical steps implemented by the Beni Suef governorate within an integrated strategy in the development of tourism are the project of developing the Nile Corniche and working to establish a Corniche from the eastern side, supporting the proposal to include Beni Suef within the path of the Holy Family, as well as work to promote an integrated program containing various types of tourism."

[Expert 2]

"The province aims to create a range of multi-purpose Nile marinas and establishing hotel resorts overlooking the Nile at all levels, in addition to the construction of the Eastern Corniche Road for $6 \mathrm{~km}$, a tourist-level Corniche that serves the tourist aspects and accommodation in the province".

[Expert 3]

\subsubsection{Proposed Plan for the Journey of Holy Family}

Beni Suef is considered the only province that can combine the journey of the Holy Family with the path of Anba Antonios who created the monastic in Christianity

"There is a proposed plan to link the journey of the Holy Family, which passed through Beni Suef, and identifying a set of points, for example, AlMaimon Monastery, the Monastery of the Virgin Mary, and any other possible locations. In addition, the inclusion of the Monastic Trail Road, which begins in the governorate of Beni Suef, which is related to the Holy Family, that begins from Al-Anba Paula and Anba Antonios and passes through the Monastery of the Virgin Mary in the Bayyad Al-Arab and then the monastery (Al-Jamiza) in the east of the Nile, to end with the monastery of Anba Paula and Anba Antonios in the Red Sea."

[Expert 4]

\subsubsection{Problems facing Tourism in Beni Suef Province}

The main problems that faced tourism in Beni Suef province represented in the period following January revolution where tourism deteriorated and lost $90 \%$ of its annual revenues in the main touristic sites, the ground water in the province is one of the main problems as well which affect the monuments in the region of Meidum, and the continuous encroachments on it, which affect negatively the work in this area

"Tourism deteriorated significantly in the period following the January revolution 2011, with tourism income for the province ranging from 8,000 to 10,000 pounds per month, therefore Beni Suef province lost $90 \%$ of its annual revenues, which are the income of visiting the Pyramid of Meidum and the Sannor Cave Protectorate Area, two of the most important tourist attractions of the province, where the income of the Pyramid of Meidum region and Sannor Cave before 2010 reached 100 thousand pounds per month".

[Expert 3] 
"The major problems facing the monuments of Beni Suef province are groundwater and the continuous encroachments on it, which affect negatively the work in this area, explaining that infringements are dealt with by editing a report by antiquities inspectors, and sending it to the tourism and antiquities police. In the case of other problems, the Directorate of Antiquities is following up with the Governor of Beni Suef".

\section{[Expert 1]}

\subsection{Students at Faculty of Tourism and Hotels Beni Suef University "Questionnaire Survey"}

The results of the questionnaire survey for the students in the fourth year, at the faculty of Tourism and Hotels, Beni Suef University, Tourism Studies departmentArabic and English section, that gathered feed back about the main touristic sites at the province, the main problems facing Beni Suef governorate, and how to develop the province in a touristic way, revealed the following statements:

\subsubsection{Gender of the Sample of the Students}

Seventy-three percent of the respondents were female (22 students); while $27 \%$ of them were male ( 8 students), which means that female students are more interested to join the faculty of tourism and hotels much more than male students

\subsubsection{Age of the Sample of the Students}

Since the questionnaire survey was distributed for the students in the fourth year, at the faculty of Tourism and Hotels, Beni Suef University, Tourism Studies department- Arabic and English section, therefore, all the students ranged from 20-22 years.

\subsubsection{Main Pharaonic Sites in Beni Suef Governorate}

More than one student stated more than one Pharaonic site, where $100 \%$ of the respondents (30 students) stated Meidum Pyramid as a main Pharaonic site, 93\% of the sample (28 students) mentioned the Area of Ahnasia, 30\% mentioned Cemetery of Abu Sir (9 students), 13\% stated Area of Dashasha (4 students) while they did not mention the Area of Al-Haiba, Sedmant Al-Jabal Archaeological Area and Abweit Antiquities Area, which shows that there are a lot of touristic Pharaonic sites in Beni Suef need to be marketed.

\subsubsection{Main Islamic Sites in Beni Suef Governorate}

Seventeen percent of the students (5 students) mentioned the minaret of the Grand Mosque "Delas" as an Islamic site; 13\% stated the Mosque of Houria (4 students), 10\% mentioned Marawan Ibn Mohammed Shehab Al-Din Umayyad cemetery (3 students), while all the students did not mention Al-Diri Mosque, Mosque of Omar Ibn-Abdul Aziz; and Al-Ghamrawi Mosque.

\subsubsection{Main Coptic Sites in Beni Suef Governorate}

Fifty-three percent of the respondents (16 students) mentioned the Monastery of Virgin Mary in Al-Hammam Area; $50 \%$ of them (15 students) mentioned the Monastery of the Virgin Mary; $40 \%$ stated Saint George Monastery in Sedmant AlJabal (12 students); and 23\% mentioned the Monastery of Anba Antonios in the Maimon area (7 students). 


\subsubsection{Other Touristic Sites in Beni Suef Governorate}

Hundred percent of the students in the survey (30 students) mentioned Wadi Sannor Cave Protectorate Area, and Beni Suef Governorate Museum as a main touristic site, while $67 \%$ of them (20 students) mentioned the Zoo as a main touristic site.

\subsubsection{Visiting Touristic Sites in Beni Suef before}

Hundred percent of the respondents (30 students) visited Meidum Pyramid, 70\% of them (21 students) visited Area of Ahnasia; 67\% of them (20 students) visited Sannor Cave Protectorate Area, 57\% of them (17 students) visited the Monastery of Saint Mary Gerges, 50\% of the students (15) had visited Beni Suef Governorate Museum, and the Zoo.

\subsubsection{Main Obstacles facing Tourism Development in Beni Suef}

All the students mentioned more than one problem that face the touristic sites in Beni Suef Province such as: the difficulty to reach these sites easily, lack of facilities such as transportation in some sites, lack of infrastructure, insufficient services for the tourists such as toilets, cafeterias and bazaars, the archaeological areas are far apart, lack of awareness, and lack of marketing and publicity

\subsubsection{Developing Touristic Sites in Beni Suef}

The students in the questionnaire survey mentioned some methods in order to develop Beni Suef governorate in a touristic way such as: make a promotional campaign via the internet, which is planned by the province for the most important tourist areas, such as the Pyramid of Meidum, Wadi Sannor Cave Protectorate Area, Islamic and Coptic regions; providing a tour guide to illustrate and explain the tourist areas, unifying the way of writing the name of Beni Suef, as in many signs it can be written in different ways such as Bani Suef, Bani Sweif, Beni Suef; Promoting the domestic tourism in the province; update the official website of Beni Suef province, and be written in more than one language such as English, French and German.

\subsection{Local Community in Beni Suef Governorate "Questionnaire Survey"}

The results of the questionnaire survey for the local community in Beni Suef governorate that gathered feed back about their knowledge of the touristic sites in Beni Suef, and if they had visited these sites or not, revealed the following statements:

\subsubsection{Gender of the Sample of the Local Community}

Sixty-four percent of the respondents were male (67); while $36 \%$ of them were female (38).

\subsubsection{Age of the Sample of the Local Community}

Thirty-seven percent of the respondents (39) were from 20 to less than 30 years old, $33 \%$ of them (35) were from 30 to less than 40 years old, $14 \%$ of them (15) were from 40 to less than 50 years old, $11 \%$ of them (11) were below 20 years old, while 5 $\%$ of them (5) were 50 years old or above.

\subsubsection{Education Level of the Sample of the Local Community}

Sixty-seven percent of the respondents (70) were graduated from universities, $14 \%$ of them (15) were still at universities, 9\% of them (10) were graduated from diploma 
and institutes, $4 \%$ of them (4) still at high schools, while $6 \%$ of them (6) were illiterate.

\section{Table 1}

Demographic Information about the Participants

\begin{tabular}{|c|l|c|c|}
\hline & & Number & Percent \\
\hline \multirow{4}{*}{ Gender } & Male & 67 & 64 \\
\cline { 2 - 4 } Total & Female & 38 & 36 \\
\hline \multirow{4}{*}{ Age } & Less than 20 years & $\mathbf{1 0 5}$ & $\mathbf{1 0 0}$ \\
\cline { 2 - 4 } & 20- less than 30 years & 11 & 11 \\
\cline { 2 - 4 } & 30- less than 40 years & 39 & 37 \\
\cline { 2 - 4 } & 40- less than 50 years & 35 & 33 \\
\cline { 2 - 4 } & 50 years or above & 15 & 14 \\
\hline Total & & $\mathbf{1 0 5}$ & 5 \\
\hline \multirow{4}{*}{ Education } & Graduated from Universities & 70 & $\mathbf{1 0 0}$ \\
\cline { 2 - 4 } & Still at Universities & 15 & 67 \\
\cline { 2 - 4 } & Graduated from Institutes and & 10 & 14 \\
\cline { 2 - 4 } & Diploma & & 9 \\
\cline { 2 - 4 } & High School & 6 & 4 \\
\cline { 2 - 4 } & Illiterate & $\mathbf{1 0 5}$ & $\mathbf{1 0 0}$ \\
\hline Total & & & \\
\hline
\end{tabular}

\subsubsection{Main Pharaonic Sites in Beni Suef Governorate}

According to the questionnaire survey that was delivered to a sample of the local community of Beni Suef, more than one person stated more than one Pharaonic site, where $45 \%$ of the respondents (47) stated Meidum Pyramid as a main Pharaonic site, $29 \%$ of the sample (30) mentioned the Area of Ahnasia, while $49.5 \%$ of the local community (52) did not mention any Pharaonic site at all, although there are Cemetery of Abu Sir, Area of Dashasha, and the Area of Al-Haiba.

\subsubsection{Main Islamic Sites in Beni Suef Governorate}

Nineteen percent only of the respondents (20) mentioned Cemetery of Marawan Ibn Mohammed as an Islamic site, while $81 \%$ did not mention any Islamic site at all, although there are other Islamic sites such as Grand Mosque Delas, Mosque of Houria, as well as mosque of Omar Ibn-Abdul Aziz.

\subsubsection{Main Coptic Sites in Beni Suef Governorate}

Thirty percent of the respondents (32) mentioned the Monastery of Saint Mary Gerges as a main Coptic site in Beni Suef, $26 \%$ of the respondents (27), stated The Monastery of Anba Antonios, 21\% of them (22) mentioned the Monastery of AlHammam as a Coptic site, where more than one person stated more than one Coptic site, while $51 \%$ of the respondents (54) did not mention any Coptic site at all, although there are other Coptic sites as Al-Mufaddal Monument and The Monastery of Virgin Mary. 


\subsubsection{Other Touristic Sites in Beni Suef Governorate}

Sixty-one percent of the respondents (64) mentioned Sannor Cave Protectorate Area as a Touristic site in the province, $51 \%$ of the respondents (54) mentioned Beni Suef Governorate Museum as a main Touristic site, while $40 \%$ of them (42) mentioned the zoo as a Touristic site, where more than one person stated more than one Touristic site, while $24 \%$ of the respondents (25) did not mention any Touristic site at all.

\subsubsection{Visiting Touristic Sites in Beni Suef before}

Thirty-eight percent of the respondents (40) had visited touristic sites before such as Meidum Pyramid, Sannor Cave Protectorate Area, Monastery of Saint Mary Gerges, Beni Suef Governorate Museum, and the Zoo, while $62 \%$ of the sample of the local community did not visit any Touristic site before although they are living in Beni Suef governorate.

\subsubsection{Main Obstacles facing Tourism Development in Beni Suef}

All the sample of the local community in Beni Suef governorate, mentioned more than one obstacle that faces the tourism development in the province, where $80 \%$ of the respondents (84 people) mentioned that lack of tourism awareness is considered a main obstacle in developing tourism in the province, $71 \%$ of them (75) mentioned that there is no clear strategy for marketing these touristic sites inside or outside Beni Suef, $55 \%$ of the sample of the local community mentioned that there is lack of adequate publicity in the media about these touristic sites, while $38 \%$ of them (40) stated that there is no proper facilities or services inside the sites that they had visited it.

\section{General Discussion}

Beni Suef governorate is a very rich province in its touristic sites, where the most important tourist attractions represent in Sannor Cave Protectorate Area, Beni Suef Governorate Museum, many recreational tourism, safari tourism, the fame of Beni Suef in the sunny climate warm winter weather, the presence of an initial tourism development represents in little existing hotel capacity, the university conference center, the relative richness of the province in its tourism resources, whether natural or environmental, and the stability of the security situation of the province, in addition to the important archaeological and historical components.

This current study evaluated the role of Beni Suef governorate in sustainable tourism development, where three main phases of fieldwork and data collection were conducted: The first phase involved in-depth, one-to-one, semi-structured interviews with government officials and experts (four at General Authority of Tourism Development), second phase involved a questionnaire administrated to students at the faculty of tourism and hotel management- Beni Suef University, The questionnaire was distributed to thirty five students, where 30 forms were returned representing $86 \%$ of the sample. The questionnaire was directed to the students within two months (November 2020- December 2020), while third phase involved a questionnaire conducted with a sample of local community in Beni Suef governorate. The questionnaire was distributed to 120 people from the local community, where 105 
forms were returned, and representing $87.5 \%$ of the sample. The questionnaire was directed to the local community within two months (June 2021- July 2021).

6.1 Beni Suef province is one of the areas with a cultural heritage, that is considered one of the most important tourism development components in the province, which qualifies it to be a touristic area, where the province was the capital of Egypt during the 9th and 10th Pharaonic dynasties, it also includes a variety of Pharaonic monuments and Coptic and Islamic relics, which are components of religious tourism, in addition to the Nile River, which is the most important natural factor that can activate the tourism movement in the province by linking Nile tourism to the patterns of tourism proposed for its development in the province, also, the province has a nature reserve, the Sannor Valley Cave Reserve, which can be used as a tourist attraction.

6.2 The governorate of Beni Suef is characterized by its proximity to the sources of tourist arrivals, where it is located within the province of Northern Upper Egypt and is in the middle of five provinces that are one of the most important tourist centers in the Republic which are (Giza, Minya, Fayoum, Red Sea, Suez) and about $121 \mathrm{~km}$ from Cairo.

6.3 Beni Suef province remained neglected for a long time ago until a tourism development strategy was prepared by the government over the next five years as part of Egypt's 2030 Vision for Sustainable Development, with the aim of gaining the province's rightful place in the Egyptian tourism map

6.4 Beni Suef province has a good network of main roads, where the Eastern Road Beni Suef- Koraymat, is one of the most efficient roads in the network. As for the road network between the province's cities, there is a medium-connected network that can be developed. Also, the province suffers from the poor condition of internal roads within the centres and villages. The main railway line Cairo-Aswan passes through the province linking the province to the provinces of the valley.

6.5 According to the questionnaire survey that was delivered to a sample of the local community of Beni Suef, $45 \%$ of the respondents stated Meidum Pyramid as a main Pharaonic site, 29\% mentioned the Area of Ahnasia, while $49.5 \%$ did not mention any Pharaonic site at all. Nineteen percent only of the respondents mentioned Cemetery of Marawan Ibn Mohammed as an Islamic site, while $81 \%$ did not mention any Islamic site at all. Thirty percent of the respondents mentioned the Monastery of Saint Mary Gerges as a main Coptic site in Beni Suef, 26\% of the respondents stated The Monastery of Anba Antonios, 21\% of them mentioned the Monastery of Al-Hammam as a Coptic site, while $51 \%$ of the respondents did not mention any Coptic site at all

6.6 The local community in Beni Suef governorate, mentioned more than one obstacle that faces the tourism development in the province, among which are the lack of tourism awareness that is considered as a main obstacle in developing tourism in the province, the unclear strategy for marketing the touristic sites inside or outside Beni Suef, the inadequate publicity about these touristic sites in the media and the inappropriateness of the facilities and/or services in such the sites. 
6.7 It is clear that the local community in Beni Suef is not interested in visiting the touristic sites in the province, as the findings of the questionnaire survey reveal that only $38 \%$ of the respondents had visited touristic sites before such as Meidum Pyramid, Sannor Cave Protectorate Area, Monastery of Saint Mary Gerges, Beni Suef Governorate Museum, and the Zoo, while 62\% of them did not visit any Touristic site before although they live in Beni Suef governorate.

6.8 The students' questionnaire survey mentioned some ways in order to develop Beni Suef governorate in a touristic way such as: making a promotional campaign via the internet, which is planned by the province for the most important tourist areas, such as the Pyramid of Meidum, Wadi Sannor Cave Protectorate Area, Islamic and Coptic regions; providing a tour guides to illustrate and explain the tourist areas, unifying the way of writing the name of Beni Suef, as in many signs it can be written in different ways such as Bani Suef, Bani Sweif, Beni Suef; promoting domestic tourism in the province; updating the official website of Beni Suef province, and providing it in more than one language (i.e. English, French and German).

\section{Recommendations}

7.1 The Ministry of Tourism and Antiquities should cooperate with the Governorate of Beni Suef, Egyptian Tourism Authority for Tourism Promotion, the General Authority for Tourism Development and representatives of tourism companies, in setting a non-traditional strategy for tourism development in Beni Suef province, such as, preparing an integrated program for internal tourism for one or two days, as the province is about an hour and a half away from Cairo, and all roads leading to the province are easy and in good condition. The tourism program should include visiting all the touristic sites in the province, both archaeological and historical monuments, and the distinctive natural areas in the province, which is suitable for internal tourism.

7.2 The Ministry of Tourism and Antiquities should merge Beni Suef governorate in the path of the Holy Family as an attractive tourism product, where the governorate is considered a link between the points of the path of the Holy Family located in Cairo (at the Virgin Church in Maadi) and the same track points located in Minya (the first of which is Jabal Al-Tair).

7.3 The Ministry of Tourism and Antiquities, in cooperation with Beni Suef province, should promote the Nile Tourism pattern in Beni Suef Governorate, where the province can be reached by Nile cruises, which leads to the activation of a distinct tourist pattern, where Beni Suef has competitive features on the Nile, a long-distance Corniche and a waterway that is the largest and shows the Nile Islands as a stunning landscape, as well as the possibility to attract floating cruise boats that take tourist trips from Cairo to Luxor and Aswan to visit the attractions of the province of Beni Suef

7.4 There should be an integration between the Tourism Development Authority and Beni Suef province to develop an integrated vision of the tourism sector, including practical steps to push the tourism flow to the province through putting 
it on the tourist map, as well as cooperation in promoting the promising components and opportunities that the province has in various types and areas of tourism, to attract investors in the field towards the relative and competitive advantages contained in the province.

7.5 Beni Suef governorate in collaboration with the General Authority of Tourism Development should spread tourism and archaeological awareness among the masses of citizens of Beni Suef adjacent to tourist and archaeological sites in order to cooperate easily with tourists, through using some methods such as media, publicity and providing training programmes for the local community in how to deal with tourists.

7.6 Beni Suef governorate should focus on the element of economic development within the tourism strategy of the province, so that improving the standard of living of the Beni Suef's citizen should become its most important consideration and should achieve development in the surrounding villages and adjacent to the Area of Pyramid of Meidum, as without the support of the local community, there will not be any tourism development in the province.

7.7 Beni Suef province should encourage Beni Suef's citizens who inhabit next to tourist and archaeological areas to work in these sites, and be a contributing factor, which is the main pillar in achieving comprehensive and sustainable development.

7.8 Beni Suef governorate should unify the way of writing the name "Beni Suef" all over the province, via the internet and through other media, as in many signs in the province, it is written in different ways such as Bani Suef, Bani Sweif, and Beni Suef.

\section{References}

- Aly, H., (2021). Beni Suef is an Integrated Touristic City within the Tourism Development Strategy, Akhbar Al-Yom Newspaper, Cairo, Egypt, 21 September, 2021, p.12.

- Amer, M., (2016). The Economical Development of Beni Suef Governorate- A Geographical Study, A Thesis submitted for a Master's degree in literature, Department of Geography and Geographic Information Systems, Beni Suef, pp 171215.

- Amerta, S., (2018). Sustainable Tourism Development, International Research Journal of Management, IT \& Social Sciences, Vol. 5No.2, March2018, ISSN: 2395-7492, pp 248-254.

- Ashley, C., (2007):Pro-Poor analysis of the Rwandan Tourism Value Chain - An emerging picture and some strategic approaches for enhancing poverty impacts, December 2007, Overseas Development Institute.

- Beni Suef Governorate Electronic Gate, (2021). Facts about Beni Suef, [online], available from: http://www.benisuef.gov.eg/New_Portal/, accessed on [20 September 2021].

- Cernat, L., and Gourdon, J., (2007). Is the Concept of Sustainable Tourism Sustainable?, Developing the Sustainable Tourism Benchmarking Tool, United 
Nations, New York and Geneva, United Nation Publication, ISSN 1816-2878, pp 325.

- Dar El-Helal, (2020). Beni Suef Governorate, [online], available from: https://www. darelhilal. com /News/739164.aspx, Dar Al-Helal Newspaper, accessed on [12 September, 2021].

- El-Garhy, A., (2021). Beni Suef on the Tourism Map-Development of the Oasis of Midum and the Creation of the Golden Triangle, Akhbar El-Yom Newspaper, 15 June 2021, p 9.

- El-Kholy, H., (2021). Vision for the Development of the Tourism Industry in Beni Suef, [online], available from: https://www.shorouknews.com/news/view. aspx? cdate $=23052021 \& \mathrm{id}=710 \mathrm{~cd} 20 \mathrm{f}-\mathrm{b} 24 \mathrm{~d}-4 \mathrm{ddd}-9 \mathrm{fb} 1-\mathrm{cb} 9029 \mathrm{e} 5 \mathrm{f} 1 \mathrm{~b} 3$, accessed on [22 August, 2021].

- El-Mahdy, O., (2021). Beni Suef Antiquities Museum, Al-Ahram Newspaper, Cairo, Egypt, p12.

- El-Sheikh, H., (2021). Ways to Implement the Region's Tourism Development Strategy, [on line], available from: https://www.albawabhnews.com/4068874, accessed on [15 August, 2021].

- El-Sheikh, O., (2020). Beni Suef Governor and Tourism Development Team Visit Midum Pyramid and Wadi Sannor, [online], available from: https://www. Almasry alyoum. com/ news/ details/2069003, accessed on [18 September, 2021].

- El-Weshahy, M., and Abd El-Wahab, M., (2016). Tourism Development in Meidum Area-Beni Suef, Journal of Association of Arab Universities for Tourism and Hospitality, Volume 13, Number 1, June 2016, Faculty of Tourism and Hotels, Suez Canal University, pp1-18

- Fakhry, N., (2021). Egypt is an Attractive Tourist Destination. Learn about the Tourism Sector Strategy in 6 Points, [online], Youm7 Electronic Newspaper, 24 september,2021, available from: https://www.youm7.com/story/2021/9/24/ , accessed on [24 September 2021].

- Fathy, H., (2017). Beni Suef is not just The Pyramid of Meidum, [online], available from: https://www.youm7.com/story/2017/ , El-Yom Al-Sabea, accessed on [15 September, 2021].

- General Authority of Tourism Development, (2016). Nile Anchor Development Project, [online], available from: http://www.tda.gov.eg/TDAprojects/NileBerthsAR.aspx, accessed on [25 August 2021].

- General Information Authority, (2021). Ministry of Planning and Economic Development announces the features of the "Citizen Investment Plan" in Beni Suef province for fiscal year 20-2021, [on line], available from: https://www.sis.gov.eg/Story/213762, accessed on [18 September, 2021].

- Global Sustainable Tourism Council, (2021). What is Sustainable Tourism?, [online], available from: https://www.gstcouncil.org/what-is-sustainable-tourism/, accessed on [2 October, 2021].

- Hafiz, M., (2021). Governor of Beni Suef meets with the General Authority for Tourism Development team, [on line], available from: https://www. dostor. org/ 3457852, accessed on [10 September, 2021].

- Kasem, A., Hassan, S., Bakry, S., and Abd -El-Mawgod, A., (2014). The Impact of Tourism Industry on Phenomena causing Poverty in the Provinces of North 
Upper (Minia, Beni Suef, Fayoum), Journal of Association of Arab Universities for Tourism and Hospitality, Volume 11, Number 2, December 2014, pp9-20

- Ministry of Tourism and Antiquities, (2021). Minister of Tourism and Antiquities discusses with the Governor of Beni Suef practical steps to boost tourism movements for the province, [on line], available from: http://www.antiquities. gov. eg/DefaultAr/pages/NewsDetails.aspx? newsid= 2159, accessed on [22 August, 2021].

- Mohsen, A., (2020). East Nile Corniche project in Beni Suef, Cairo, Egypt, ElNabaa Newspaper, 18 August 2020, p 11.

- Murphy, P. and Murphy, A. (2004). Strategic management for tourism communities: Bridging the gaps, Ontario: Channel View Publication, p.p 35-47.

- N-Egypt, (2019). The Most Important Tourist Attractions in Beni Suef, [online], available from: https://negypt.net/ar/, accessed [19 September, 2021].

- Nour El-Deen, A., (2001). Egyptian Antiquities Sites and Museums, Arabian Gulf for printing and publishing, Egypt, Cairo, pp.98-123.

- Pender, L. and Sharpley, R. (2005): The Management of Tourism. London: Sage Publications, p.p 18-20.

- Ragab, A., (2020). Practical steps to promote the province of Beni Suef in a Touristic way, [on line], available from: https://www.elwatannews.com/news/ details/5006383, accessed on [5 August 2021].

- Rezk, A., (2020). Minister of Tourism discusses with Beni Suef governor practical steps to boost tourism in the governorate, [on line], available from: https://tourismdailynews. com/2020/09/27, accessed on [2 September, 2021].

- Saleh, S., (2021). The Pearl of Upper Egypt, History of Beni Suef Governorate, ElWatan Newspaper, [online], available from: https://www.elwatannews.com/ news/details/ 5396894? $\mathrm{t}=$ push, accessed on [17 September 2021].

- Saufi, A., O'Brien, D., and Wilkins, H., (2014). Inhibitors to host community participation in sustainable tourism development in developing countries, Journal of Sustainable Tourism, Volume 22, 2014, Issue 5,pp18-29.

- Serag El-Deen, A., (2012). Tourism Development Geography of Beni Suef Governorate, Arab Geographical Magazine, Cairo, Egypt, pp 195-248.

- Shaheen, M., (2021). El-Nahda University design the project of the Corniche east of the Nile, [on line], available from: https://edu.see.news/2020/08/10/, accessed on [7 September, 2021].

- Soliman, H., (2020). The General Authority for Tourism Development is searching for setting Beni Suef on the tourist map, [online], available from: https://www.masrawy.com/ news/ news regions/details, accessed on [10 September 2021].

- Theobald, W., (2005). Global Tourism. Burlington: Elsevier Inc, p.p 18-23.

- Tourism Promotion Authority in Beni Suef, (2019). Tourism Statistics, Beni Suef.

- UNDP, (2017). Tourism and the Sustainable Development Goals - Journey to 2030, [online], available from: https://www.e-unwto.org/doi/pdf/10.18111 19789284419401, accessed on [2 October 2021].

- Weaver, D. and Lawton, L. (2006): Tourism Management. Milton: John Wiley \& Sons, p.p 14-21. 


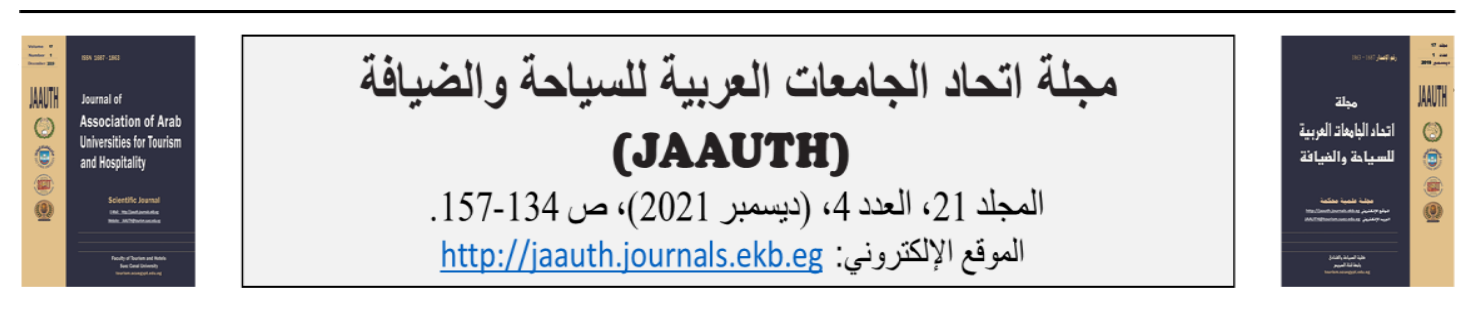

\section{بني سويف - لؤلؤة الصعيد - ودورها في التنمية السياحية المستدامة}

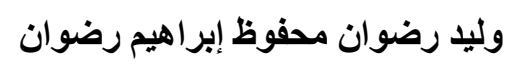

قسم الدر اسات السياحية، كلية السياحة و الفنادق، جامعة حلو إنمان، رضوان القاهرة، مصر

\begin{tabular}{|c|c|}
\hline الملخص & معلومات المقالة \\
\hline تعد محافظة بني سويف من أكثر المحافظات الواعدة في صعيد مصر، حيث & الكلمات المفتاحية \\
\hline تتميز بموقع استراتيجي ورؤية متكاملة وخبرة تنفيذية تسهم في وضع المحافظة & محافظه بني سويف؛ هرم \\
\hline على خريطة الاستثمار والسياحة. تعد بني سويف من أهم المحافظات الواقعة & 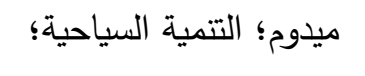 \\
\hline جنوب العاصمة المصرية القاهرة، مع توافر العديد من أماكن الجذب السياحي & الآثار • \\
\hline الهامة في المحافظة، حيث تتميز بوجود العديد من الآثار الفرعونية والإسلامية & \\
\hline والقبطية، بالإضافة إلى متحف يحتوي على العديد من الآثار من فترات مختلفة & \\
\hline مثل الرومانية والفرعونيه واليونانية والقبطية والإسلامية، وكذلك منطقة محمية & (JAAUTH) \\
\hline كهف وادي سنور، حيث يعود تاريخ هذا الكهف إلى 65 مليون سنة. تضمنت & المجلد 21، العدد 4)، \\
\hline طريقة جمع البيانات الرئيسية إجراء مقابلات شخصيه معققة وشبه منظمة مع & ص ص (154-134. \\
\hline مسئولين حكوميين بالهيئة العامة للتتمية السياحية، وشملت المرحلة الثانية & \\
\hline استبيان تم توزيعه على طلاب كلية السياحة والفنادق - جامعة بني سويف، فى & \\
\hline حين تضمنت المرحلة الثالثة استبيان تم إجراؤه مع عينة من المواطنين بمحافظة & \\
\hline بني سويف. توصي الدراسه بأنه ينبغى على وزارة السياحة والآثار دمج محافظة & \\
\hline بني سويف في مسار العائلة المقدسة كمنتج سياحي جذاب، حيث تعتبر & \\
\hline المحافظة حلقة وصل بين نقاط مسار العائلة المقدسة الموجودة بالقاهرة (في & \\
\hline كنيسة العذراء بالمعادي) ونفس نقاط المسار الموجودة بالمنيا (أولها جبل & \\
\hline الطير )، كما يجب على محافظة بني سويف بالتعاون مع الهيئة العامة للتمية & \\
\hline رر الوعي السياحي والأثري بين جماهير المواطنين بيني سويف & \\
\hline واقع السياحية والأثرية من أجل التعاون بسهولة مع السائحين. & \\
\hline
\end{tabular}

